\title{
Power Laws in Cone Production of Longleaf Pine across Its Native Range in the United States
}

\author{
Xiongwen Chen ${ }^{1}$, Qinfeng Guo ${ }^{2} \&$ Dale G. Brockway ${ }^{3}$ \\ ${ }^{1}$ Department of Biological and Environmental Sciences, Alabama A\&M University, Normal, AL 35762, USA \\ ${ }^{2}$ USDA Forest Service Eastern Forest Environmental Threat Assessment Center, 3041 E. Cornwallis Road, \\ Research Triangle Park, NC 27709, USA \\ ${ }^{3}$ USDA Forest Service, Southern Research Station, 521 Devall Drive, Auburn, AL 36849, USA \\ Correspondence: Xiongwen Chen, Department of Biological \& Environmental Sciences, 139 ARC building, \\ Alabama A \& M University, Normal, AL, USA. Tel: 256-372-4231. E-mail: xiongwen.chen@ aamu.edu
}

$\begin{array}{lc}\text { Received: July 8, } 2017 & \text { Accepted: August 19, } 2017 \quad \text { Online Published: August 28, } 2017 \\ \text { doi:10.5539/sar.v6n4p64 } & \text { URL: https://doi.org/10.5539/sar.v6n4p64 }\end{array}$

\begin{abstract}
Longleaf pine (Pinus palustris Mill.) forests in the southeastern United States are considered endangered ecosystems, because of their dramatic decrease in area since European colonization and poor rates of recovery related to episodic natural regeneration. Sporadic seed production constrains restoration efforts and complicates sustainable management of this species. Previous studies of other tree species found invariant scaling properties in seed output. Here, using long-term monitoring data for cone production at seven sites across the native range of longleaf pine, we tested the possible presence of two types of power laws. Findings indicate that (i) the frequency distribution of cone production at seven sites, from 1958 to 2014, follows power law relationships with high level of significance; (ii) although there is no general trend in the dynamics of scaling exponents among all sites, there are dynamics of scaling exponents at each site, with sudden changes in scaling exponents generally corresponding to the years of higher or lower cone production; and (iii) Taylor's power laws explain cone production at different locations, but the scaling exponents vary among these. Results from this computational approach provide new insight into the irregular cone production of longleaf pine at spatial and temporal scales. Integrated ecosystem monitoring will be necessary to more fully understand future changes in cone production.
\end{abstract}

Keywords: discontinuity, Pinus palustris, reproduction, scaling exponents, sustainability

\section{Introduction}

Longleaf pine (Pinus palustris Mill.) forests are important ecosystems in the southeastern United States, because of their economic (e.g., timber and related wood products) and ecological value (e.g., high biodiversity, wildlife habitat, watershed protection) (Jose, Jokela, \& Miller, 2006; Hodges, 2006). However, the area occupied by longleaf pine ecosystems decreased from about 37 million hectares to 1.02 million hectares, between the time of European settlement and late $20^{\text {th }}$ century (Outcalt \& Sheffield, 1996). Thus, longleaf pine forests have become regarded as endangered ecosystems (Noss, Laroe, \& Scott, 1995).

In addition to fire exclusion and land use change, one of the most important factors contributing to the decline of longleaf pine forests has been their sporadic seed production (Frost, 2006). Although previous studies considered climate factors (e.g., temperature and precipitation) as possible determinants of cone production (Pederson, Kush, \& Meldahl, 1998; Pederson, Kush, Meldahl, \& Boyer, 2000), later work found that the relationships between climate and cone production were not strong (Guo, Zarnoch, Chen, \& Brockway, 2016; Patterson, 2017). Since the quantity of seed produced directly affects longleaf pine forest regeneration, timber supply, wildlife habitat and food chains, it is important to further study the spatial and temporal variance of cone production from different perspectives. Analyzing the patterns of irregular seed production may provide information essential for expanding our understanding of fundamental reproduction processes and improving forest management.

If existing trees cannot produce sufficient cone crops for regeneration, then populations of longleaf pine may face local extinction. Thus the structure and function of entire ecosystems dependent on this keystone species could be profoundly changed. If stewardship programs are to be successful in the future, then, adaptive 
management needs to understand this source of uncertainty and make suitable accommodation for it. The limitations of short-term and single site studies (e.g., incompleteness and bias) were revealed in a long-term and multi-site study by Guo et al. (2016). Results from one site, based on a short period of observation, were not consistent with results from a larger number of sites, observed through a longer time period. Since seed production is a lengthy multi-year processes, many unfavorable factors may adversely influence results. Scientists and managers still lack a general model for predicting cone production at individual longleaf pine sites across the region or overall cone production relative to the spatial and temporal heterogeneity inherent across its native range. Comparisons of complexity, such as cone production entropy at regional and local levels and through time (Chen, Guo, \& Brockway, 2016; Chen, Brockway, \& Guo, 2016), may provide new insights about cone production from a perspective not previously explored. Toward the ends of developing useful models and sustainable management strategies for longleaf pine forests at the regional and local scales, new knowledge about the emergent behavior of cone production (e.g., regime shift) needs to be developed.

Since all biological systems must transform energy and materials to support various life functions and structures, they may obey a host of remarkably simple and systematic empirical scaling laws that regulate how organisms change across many orders of magnitude (West, 1999). In statistics, a power law describes a functional relationship between two quantities, where a relative change in one quantity results in a proportional relative change in the other quantity: one varies as a power of another. Power law relationships have been used to characterize the scaling laws for all kinds of life forms (Enquist, Brown, \& West, 1998; West, 1999), because of their linkage to the rates of many biological activities at various hierarchical levels of organization and they represent a holistic measure of the 'pace of life'. Power laws are considered as ubiquitous in nature and are broadly found in the distribution of drainage area for rivers, rain droplet size, populations of cities and earthquakes (Zipf, 1949; Gutenberg \& Richter, 1956; Bak, 1996).

Recent controversy has arisen concerning whether the scaling exponents of power laws are a universal value (e.g., $1 / 4$ or 1/3) or other non-fixed values (Chen \& Li, 2003; Glazier, 2005; Kolokotrones, Savage, Deeds, \& Fontana, 2010). Despite fluctuations in seed production, trees frequently exhibit a broad continuum of reproductive consistency (Herrera, Jordano, Guitian, \& Traveset, 1998, Koenig \& Knops, 1998; 2000). Kerkhoff and Ballantyne (2003) found invariant scaling properties in seed output for 28 tree species with 148 reproductive time series in Europe (Koenig \& Knops, 2000). Thus, we may derive a hypothesis that there exists possible scaling invariance in the cone production for longleaf pine across its native range. The goal of this study is to use long-term monitoring data to (i) test whether cone production of longleaf pine at different sites follows power laws; (ii) test whether cone production of longleaf pine at different locations across its native range follows the same or similar power laws through time; and (iii) discuss the possible implications of power laws for understanding the cone production of longleaf pine.

\section{Materials and Methods}

\subsection{Data}

Cone production of longleaf pine has been observed by scientists at the Southern Research Station of the USDA Forest Service using binoculars each spring at numerous sites across its native range since 1958. In low-density stands (basal area $<9.2 \mathrm{~m}^{2} \mathrm{ha}^{-1}$ ) at each site, data were collected by counting the number of green cones in the crowns of 10 mature longleaf pine trees, as part of a long-term monitoring study. The mean number of green cones on all sampled trees was used to represent the average cone production for each site. Detailed information can be found in Brockway (2015). Seven of these sites, having the longest data records, were selected for our analysis. These sites included the (1) Escambia Experimental Forest in southern Alabama, (2) Red Hills of northern Florida, (3) Blackwater River State Forest in the western panhandle of Florida, (4) Jones Ecological Research Center in southwestern Georgia, (5) Sandhills State Forest in northeastern South Carolina, (6) Kisatchie National Forest in central Louisiana, and (7) Eglin Air Force Base in the Florida panhandle.

\subsection{Methods}

Two types of power laws were tested in this study.

\section{(i) Power law of frequency}

Cone production numbers were sorted based on increments of 20 cones. For example, a production level of 120 cones had the following length categories associated with it: $\leq 20, \leq 40, \leq 60, \ldots \leq 120$ ). The number of cones produced within each category was counted. For each research site, the cumulative percentage of probability for the number of cones within each category was then calculated (White, Enquist, \& Green, 2008). Finally, a figure with the logarithm of cone production $(m)$ and the logarithm of the cumulative probability $(P)$ was produced. To 
be consistent with the literature on the estimation of allometric relationships (e.g., Chen \& Li, 2003), a reduced major axis (RMA) of regression analysis Model Type II was used to determine scaling exponents ( $\alpha$ RMA) for different sites.

$$
P(m)=a \times m^{b}
$$

with $a$ as the coefficient and $b$ as the exponent of the scaling relationship between frequency $(P)$ and the category $(m)$. After logarithm, $\log (P)=\log (a)+b \log (m)$, here $\log =\log _{10}$.

At each research site, the dynamics of the scaling relationship were studied through time.

(ii) Power law between average and variance

Taylor (1961) and colleagues observed that, in many species, the logarithm of the variance of the density (individuals per area or volume) of populations was approximately a linear function of the logarithm of the mean density. This relationship has been known as Taylor's Law. Taylor's Law is one of the most widely verified empirical relationships in ecology. It was verified in hundreds of species including trees (Cohen, Xu, \& Schuster, 2012; 2013). For our study, Taylor's Law can be expressed in the following way for this study:

$V=a M^{-b}$, with $V$ as the variance of cone production, $M$ the average of cone production.

After logarithm, $\log (V)=\log (a)-b \log (M)$. With the time increase of $1,2 \ldots$ to $n$ years from the early time, the scaling exponents between the variance and average of cone production were estimated.

\section{Results}

Through 2014, temporal distribution in the magnitude of cone production for longleaf pine at different locations within its range followed power law relationships significantly (Table 1, Figure 1). Overall, scaling exponents ranged from 0.14 to 0.62 with $0.14 \sim 0.17$ at the Blackwater, Jones Center and Eglin sites, $0.23 \sim 0.33$ at the Escambia, Sandhills and Kisatchie sites and about 0.62 at the Red Hills site.

Table 1. Power laws of frequency for cone production in longleaf pine through 2014 in the southeastern United States

\begin{tabular}{|l|l|l|l|l|l|l|}
\hline $\begin{array}{l}\text { Site } \\
\text { information }\end{array}$ & $\begin{array}{l}\text { Escambia } \\
\text { Experimental } \\
\text { Forest (Alabama) }\end{array}$ & $\begin{array}{l}\text { Red Hills } \\
\text { (Florida) }\end{array}$ & $\begin{array}{l}\text { Blackwater } \\
\text { River State } \\
\text { Forest (Florida) }\end{array}$ & $\begin{array}{l}\text { Jones } \\
\text { Center } \\
\text { (Georgia) }\end{array}$ & $\begin{array}{l}\text { Sandhills } \\
\text { State Forest } \\
\text { (South } \\
\text { Carolina) }\end{array}$ & $\begin{array}{l}\text { Kisatchie } \\
\text { National } \\
\text { Forest } \\
\text { (Louisiana) }\end{array}$ \\
\hline $\begin{array}{l}\text { Observation } \\
\text { years }\end{array}$ & $\begin{array}{l}57 \\
(1958-2014)\end{array}$ & $\begin{array}{l}16 \\
(1999-2014)\end{array}$ & $\begin{array}{l}48 \\
(1967-2014)\end{array}$ & $\begin{array}{l}\text { Eglin } \\
\text { force Base } \\
\text { (Florida) } \\
(1967-2014)\end{array}$ & $\begin{array}{l}46 \\
(1969-2014) \\
(1967-1974, \\
1977-2014)\end{array}$ \\
\hline Exponent & 0.2341 & 0.6227 & 0.1409 & $\begin{array}{l}41 \\
(1968-1987, \\
1994-2014)\end{array}$ \\
\hline $\mathrm{R}^{2}$ and $\mathrm{P}$ & $\begin{array}{l}\mathrm{R}^{2}=0.9477 \\
\mathrm{P}<0.01\end{array}$ & $\begin{array}{l}\mathrm{R}^{2}=0.9839 \\
\mathrm{P}<0.01\end{array}$ & $\begin{array}{l}\mathrm{R}^{2}=0.8544 \\
\mathrm{P}<0.01\end{array}$ & $\begin{array}{l}\mathrm{R}^{2}=0.8959 \\
\mathrm{P}<0.01\end{array}$ & $\begin{array}{l}\mathrm{R}^{2}=0.9395 \\
\mathrm{P}<0.01\end{array}$ & $\begin{array}{l}\mathrm{R}^{2}=0.8908 \\
\mathrm{P}<0.01\end{array}$ \\
\hline
\end{tabular}




\section{Escambia}

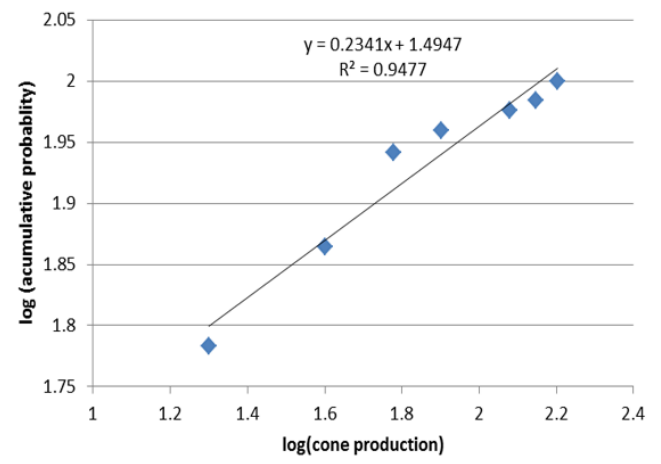

\section{Blackwater}

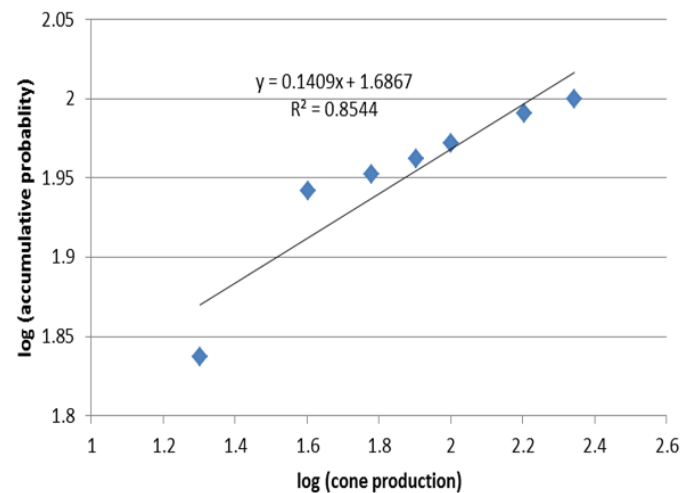

\section{Sandhills}

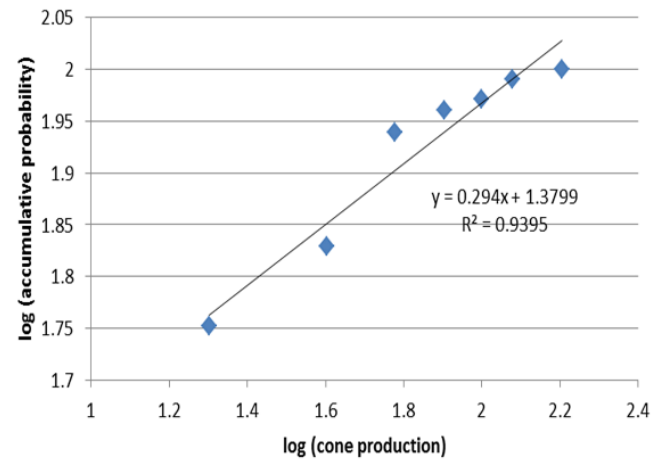

\section{Eglin}

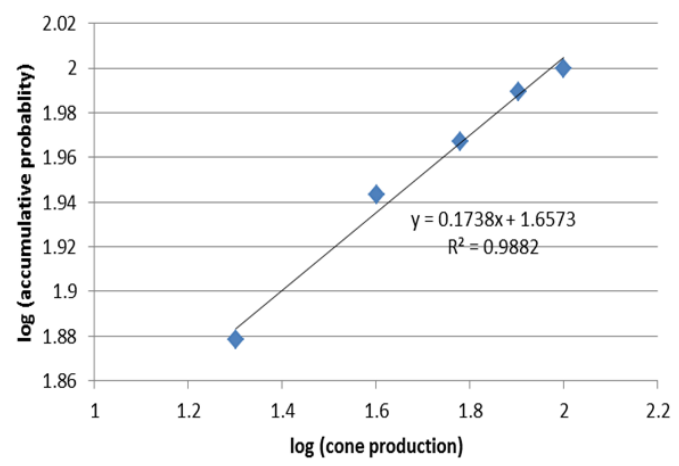

\section{Red Hills}

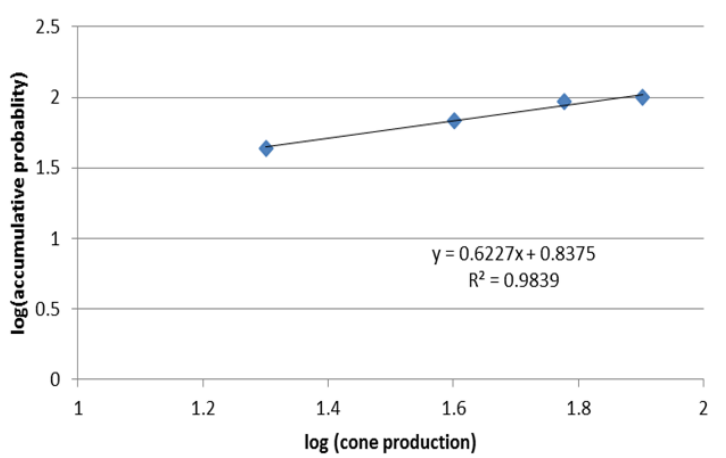

\section{Jones Center}

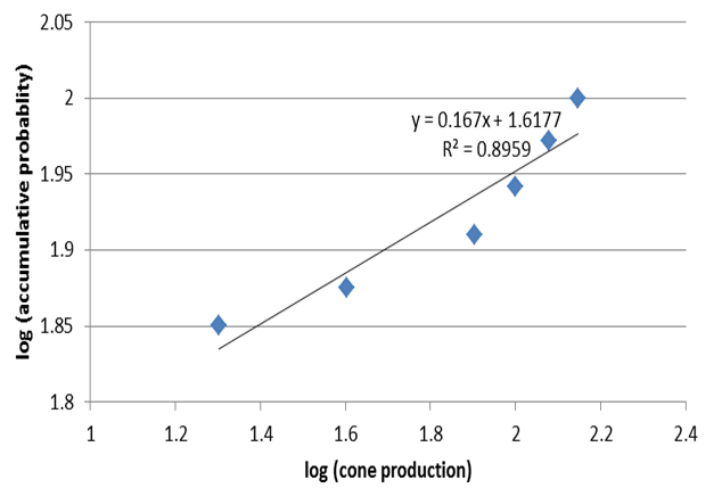

\section{Kashachie}

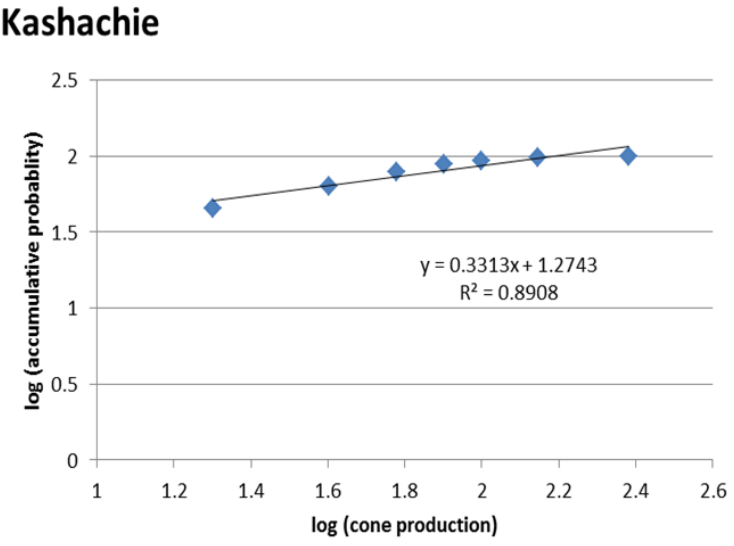


Dynamics of scaling exponents were present at each site (Figure 2). Scaling exponents were typically higher in the beginning and become lower through time. Sudden changes (or breaks) in scaling exponents generally corresponded to the higher or lower output years for cone production in longleaf pine. There was no general trend in the dynamics of scaling exponents among all sites (Figure 2).

\section{Escambia}

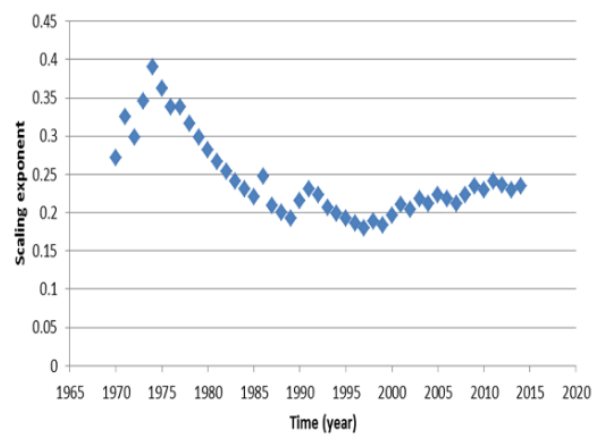

\section{Blackwater}

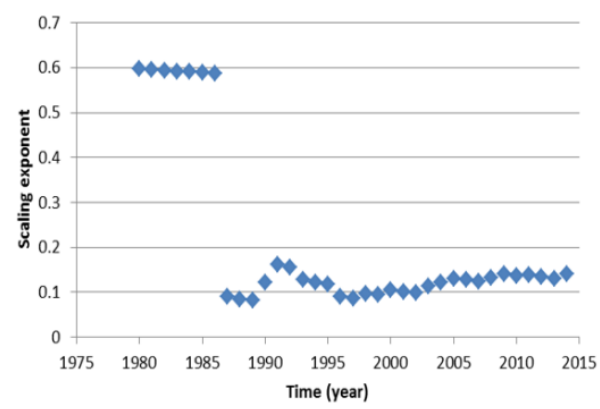

\section{Sandhills}

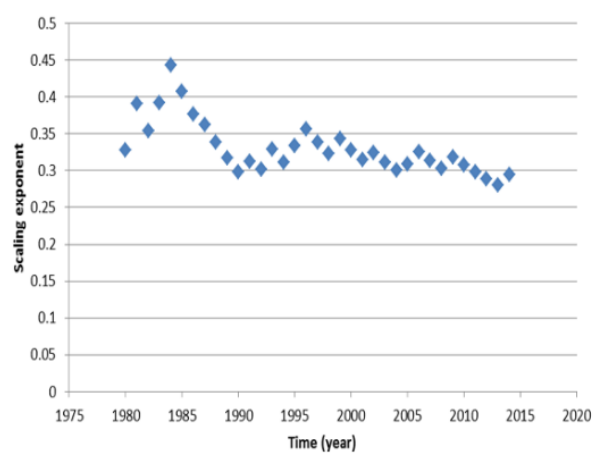

\section{Eglin}

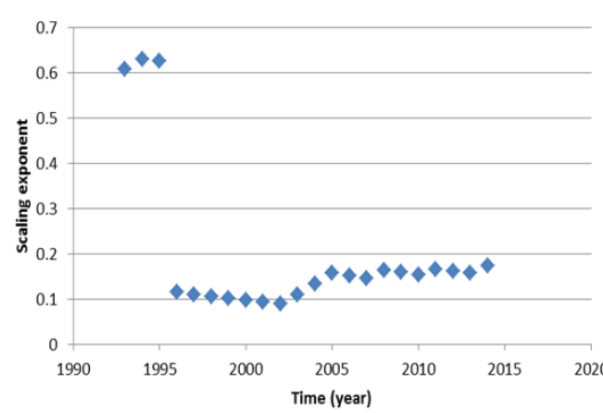

\section{Red Hills}

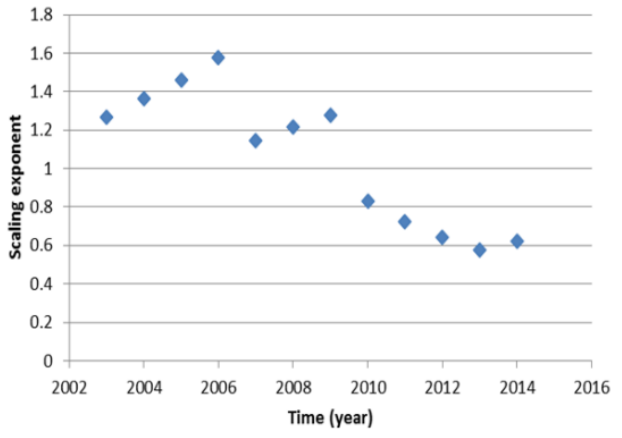

Jones Center

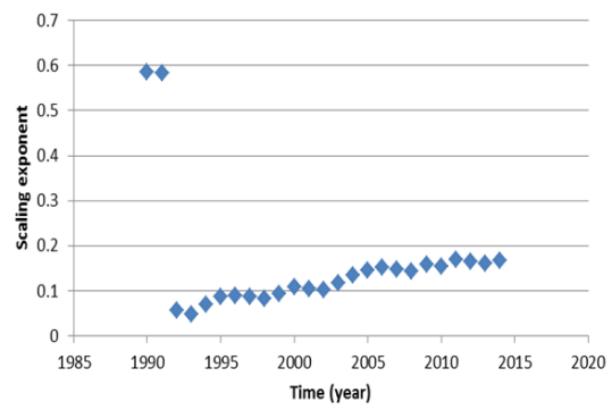

\section{Kashachie}
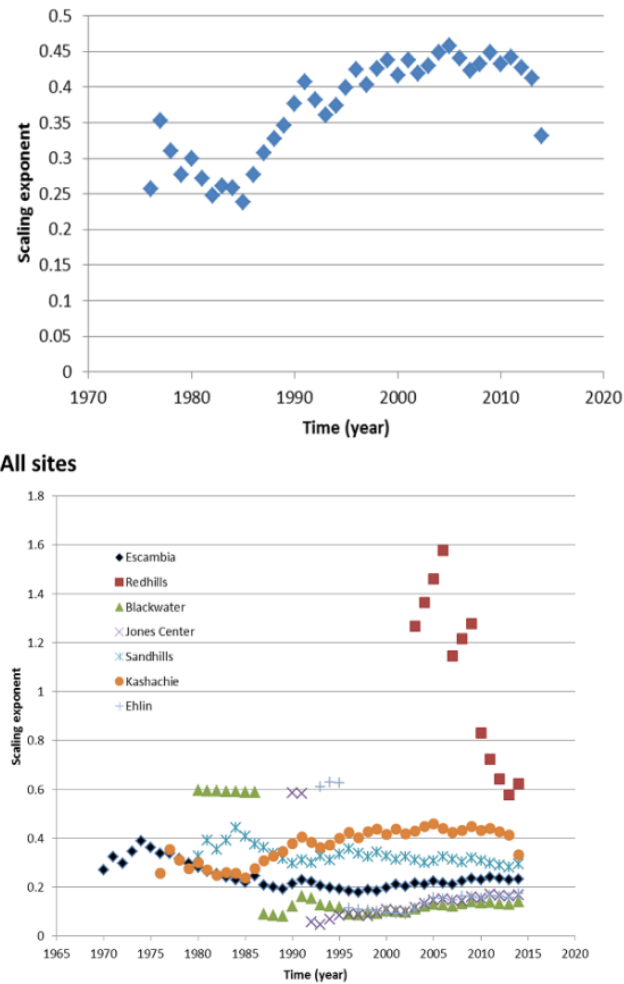

Figure 2. Dynamics of scaling exponents in power laws of frequency for cone production in longleaf pine forests of the southeastern United States 
Taylor's Law relationships were also evident, between the average and variance of cone production through time, for longleaf pine stands at different locations across the native range, except for the Red Hills site in Florida (Figure 3). Scaling exponents concentrated within 2.3 2.8 at four sites (Escambia, Blackwater, Jones Center, and Eglin), but were 4.2569 at the Sandhills site, -0.4616 for the Red Hills site and 3.5874 at the Kisatchie site. All scaling exponents were beyond the extent of $[1,2]$.

\section{Escambia}

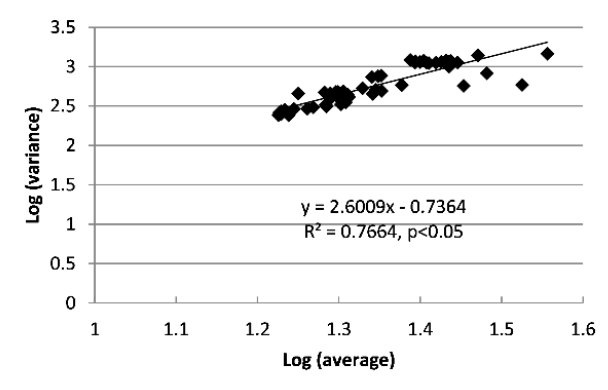

\section{Blackwater}

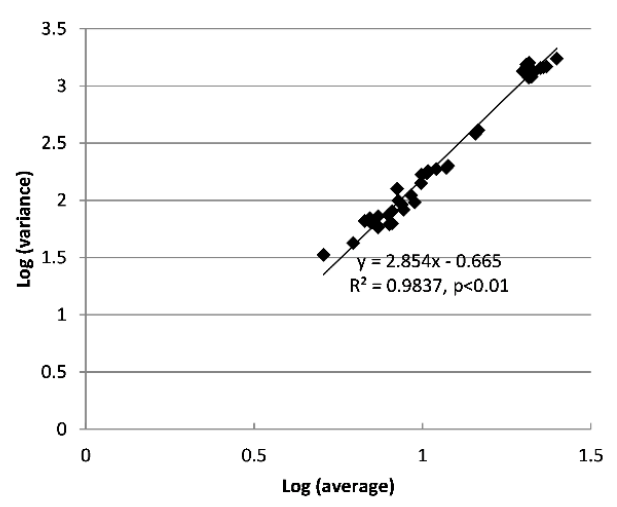

\section{Sandhills}

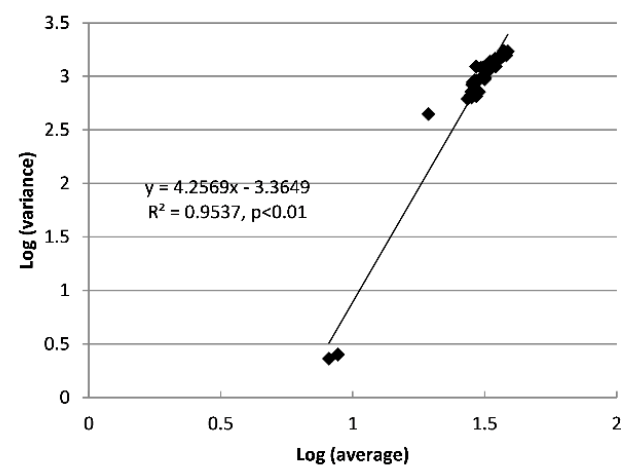

Eglin

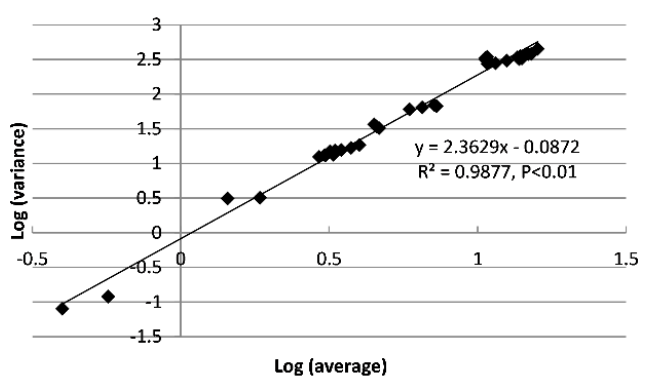

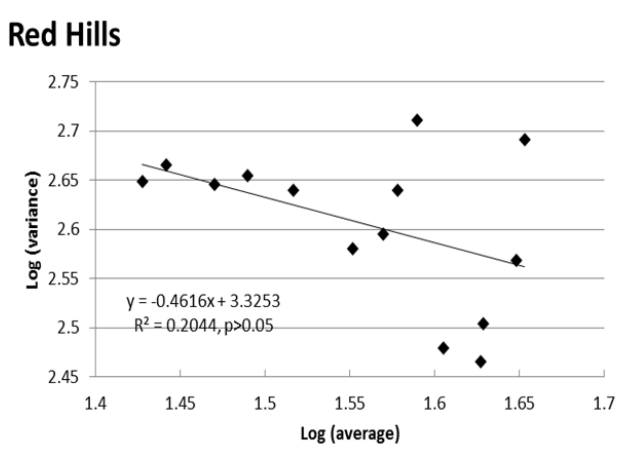

\section{Jones Center}

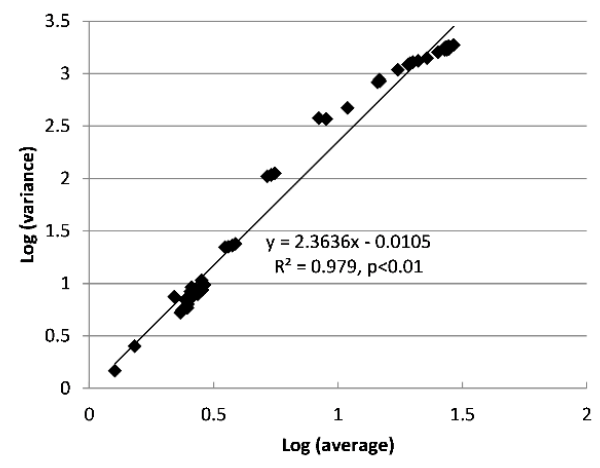

\section{Kisatchie}

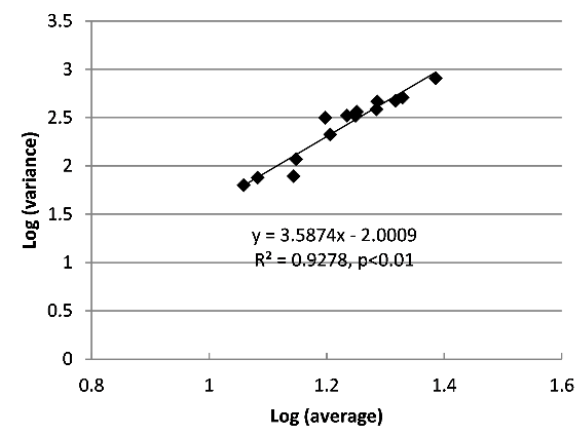

Figure 3. Taylor's Laws for cone production in longleaf pine forests of the southeastern United States 


\section{Discussion}

The power law of frequency distribution is typically displayed as simple histograms of the quantity of interest. There is substantial interest in the exponents of power-law distributions to infer about the functions underlying the distributions, to test mechanistic models, and to estimate and predict patterns and processes from which the observed data are derived (Kerkhoff \& Enquist, 2007). Usually the exponents are within the extent of [1,3]. When the exponent approaches 1, it is considered to represent stochastic processes (Zillio \& Condit, 2007). In this study, the three groups of exponents may represent different cone production behaviors. The scaling exponents, decreasing from high to low values at the Red Hills site, were quite different than at other locations, which might mean a different pattern of self-organized cone production. Power laws are thought to characterize information in a system from disorder to order (Cao et al., 2016). Similar power laws for the frequency of cone production among spatially separated sites may propose that intrinsic biological traits (e.g., hormones or other chemical growth regulators) may be responsible for the growth patterns (Suzuki \& Suzuki, 2009). Our study on the complexity of cone production indicated that cone production at these sites shares some common features across scales (Chen et al., 2016a, b). Power laws of frequency can also be used to make predictions for new observations of cone production.

Temporal dynamics for scaling exponents in the power law of frequency indicate that there is no scaling invariance in the frequency of cone production at different sites across the native range. There is no general trend shared by all scaling exponents. Scaling exponents are neither $3 / 4$ nor $1 / 3$, but rather range from 0.2 to 1.6 . Through time, scaling breaks often occur in cone production at each site. These breaks may support the existence of discontinuities in ecological processes (Holling, 1992; Allen, Forys, \& Holling, 1999). The timing of these scaling breaks generally corresponds to years with higher cone production (e.g., masting). Comparing the scaling regimes through time at different sites can show the dynamics of scaling exponents and clarify issues related to scaling exponents from a single point in time. The scaling exponent may also indicate that the complexity of cone production may be a tradeoff between intrinsic biological factors and external environmental factors (Chen et al., 2016a, b). Mechanisms for the fluctuation of scaling exponents are not clear. Simini, Anfodillo, Carrer, Banavar, \& Maritan (2010) suggested that power law behavior depends on resources availability. However, it is not clear here which resource factors (e.g., temperature, water, and nutrients) can affect scaling behavior for longleaf pine, because of limited information about numerous environmental variables.

Taylor's Law applies to longleaf pine, emphasizing the relationship between the average and variance of cone production through time, although the scaling exponents vary with location. Usually, the mean and variance increase together. The scaling exponent is higher than 0 and, in many cases, it is within $[1,2]$ (Marquet et al., 2005). The higher exponent reflects greater heterogeneity from a pure random distribution. When the exponent is higher than 2, it may propose deterministic and exponential growth (Ballantyne, 2005; Cohen et al., 2013). An earlier study about individual trees also found that the scaling exponent did not fall within the proposed range (Cohen et al., 2012). Differences in the scaling exponents may reflect the ability of differing life habits (e.g., parasitism or epidemic infection) to alter power laws (Lagrue, Poulin, \& Cohen, 2015; Morand \& Krasnov, 2008). Arruda-Neto et al. (2012) indicated that the scaling exponent $(1<$ exponent $<2)$ is intimately associated with long-range interactions among all the elements of a given system, plus negative interactions among them within a community. The higher scaling exponents at the Sandhills, Red Hills and Kisatchie sites may reflect the effects from interactions within a local ecosystem.

Power law relationships are observed in cone production for longleaf pine at different sites across the southeastern United States. This suggests that cone production is a self-organized and self-similar process, because the power laws are often associated with complexity arising from critical phenomena in a self-organizing system (Milne, 1998). However, these power laws have dynamics in scaling exponents, such as breaks in scaling exponents, associated with increases in cone production. These results provide new insight about cone production in longleaf pine forests. The scaling relationships better inform our understanding of the resilience and change that is characteristic of these ecological systems (Kerkhoff \& Enquist, 2007).

Unfortunately, we were not able to address the resilience issue, because ecosystem level data (e.g., water availability, soil nutrients, and fire history) were lacking for these longleaf pine study sites. Our results may generate additional questions, such as which factors determine the speed and variance direction of power laws for cone production in longleaf pine? Given the complexity in cone production at regional and local levels and through time (Chen et al., 2016a, b), further studies of power laws could indeed provide additional insights about cone production for sustainable management of longleaf pine forests. Future studies are needed, which integrate longleaf pine cone production with numerous environmental variables, as well as assess emergent behaviors in cone production, such as those indicated by regime shifts across sites and time scales. 


\section{Acknowledgements}

This work was partially supported by the USDA National Institute of Food and Agriculture McIntire Stennis project (1008643).

\section{References}

Allen, C. R., Forys E. A., \& Holling C. S. (1999). Body mass patterns predict invasions and extinctions in transforming landscapes. Ecosystems, 2, 114-121. https://doi.org/:10.1007/s100219900063

Arruda-Neto, J. D. T., Bittencourt-Oliveira, M. C., Castro, A. C., Rodrigues, T. E., Harari, J., Mesa, J., \& Genofre, G. C. (2012). Global warming and the power-laws of ecology. Atmospheric and Climate Sciences, 2, 8-13. https://doi.org/10.4236/acs.2012.21002

Ballantyne, F. (2005). The upper limit for the exponent of Taylor's power law is a consequence of deterministic population growth. Evolutionary Ecology Research, 7, 1213-1220.

Bak, P. (1996). How Nature Works: The Science of Self-Organised Criticality. New York, NY: Copernicus Press. https://doi.org/10.1007/978-1-4757-5426-1

Brockway, D. G. (2015). Longleaf Pine Cone Prospects for 2015 and 2016. Available online at www.srs.fs.usda.gov/longleaf/products/2015_REPORT_on_Longleaf_Pine_Cone_Production.pdf; last accessed Dec. 2, 2016.

Cao, Y., Zhao, Y., Yue, X., Xiong, F., Sun, Y., He, X., \& Wang, L. (2016). Between disorder and order: A case study of power law. Physica A, 456, 244-255. https://doi.org/10.1016/j.physa.2016.03.045

Chen, X., \& Li, B. L. (2003). Testing the allometric scaling relationships with seedlings of two species. Acta Oecologia, 24, 125-129. https://doi.org/10.1016/S1146-609X(03)00062-6

Chen, X., Guo, Q., \& Brockway, D. G. (2016a). Analyzing the complexity of cone production in longleaf pine by multiscale entropy. Journal of Sustainable Forestry, 35, 172-182. https://doi.org/10.1080/10549811.2015.1135294

Chen, X., Brockway, D. G., \& Guo, Q. (2016b). Entropy dynamics in cone production of longleaf pine forests in the southeastern United States. Mathematical and Computational Forestry and Natural-Resource Sciences, $8,11-15$.

Cohen, J. E., Xu, M., \& Schuster, W. S. F. (2012). Allometric scaling of population variance with mean body size is predicted from Taylor's law and density-mass allometry. Proceedings of National Academy of Sciences USA, 109, 15829-15834. https://doi.org/10.1073/pnas.1212883109

Cohen, J. E., Xu, M., \& Schuster, W. S. F. (2013). Stochastic multiplicative population growth predicts and interprets Taylor's power law of fluctuation scaling. Proceedings of Royal Society of London B, 280, 20122955. https://doi.org/10.1098/rspb.2012.2955

Enquist, B. J., Brown, J. H., \& West, G. B. (1998). Allometric scaling of plant energetics and population density. Nature, 395,163-165. https://doi.org/10.1038/25977

Frost, C. C. (2006). History and future of the longleaf pine ecosystem. In S. Jose, E. J. Jokela, \& D. L. Miller (Eds.), The Longleaf Pine Ecosystem: Ecology, Silviculture, and Restoration (pp. 9-42). New York, NY: Springer Science. https://doi.org/10.1007/978-0-387-30687-2_2

Glazier, D. S. (2005). Beyond the "3/4-power law": Variation in the intra- and interspecific scaling of metabolic rate in animals. Biological Review, 80, 611-662. https://doi.org/10.1017/S1464793105006834

Guo, Q., Zarnoch, S. J., Chen, X., \& Brockway, D. G. (2016). Life cycle and masting of a recovering keystone indicator species under climate change. Ecosystem Health and Sustainability, 2(6), e01226. https://doi.org/10.1002/ehs2.1226

Gutenberg, B., \& Richter, C. F. (1956). Magnitude and Energy of Earthquakes. Annali di Geofisica, 9, 1-15.

Herrera, C. M., Jordano, P., Guitian, J., \& Traveset, A. (1998). Annual variability in seed production by woody plants and the masting concept: Reassessment of principles and relationship to pollination and seed dispersal. American Naturalist, 152, 576-594. https://doi.org/10.1086/286191

Hodges, A. W. (2006). The naval stores industry. In S. Jose, E. J. Jokela, \& D. L. Miller (Eds.), The Longleaf Pine Ecosystem: Ecology, Silviculture, and Restoration (pp. 43-48). New York, NY: Springer Science.

Holling, C. S. (1992). Cross-scale morphology, geometry, and dynamics of ecosystems. Ecological Monographs, 


\section{2, 447-502. https://doi.org/10.2307/2937313}

Jose, S., Jokela, E. J., \& Miller, D. L. (2006). The Longleaf Pine Ecosystem: An overview. In S. Jose, E. J. Jokela, \& D. L. Miller (Eds.), The Longleaf Pine Ecosystem: Ecology, Silviculture, and Restoration (pp. 3-8). New York, NY: Springer Science. https://doi.org/10.1007/978-0-387-30687-2

Kerkhoff, A. J., \& Ballantyne, I. V. (2003). The scaling of reproductive variability in trees. Ecology Letters, 6, 850-856. https://doi.org/10.1046/j.1461-0248.2003.00513.x

Kerkhoff, A. J., \& Enquist, B. J. (2007). The implications of scaling approaches for understanding resilience and reorganization in ecosystems. BioScience, 57, 489-499. https://doi.org/10.1641/B570606

Koenig, W. D., \& Knops, J. M. H. (1998). Scale of mast-seeding and tree-ring growth. Nature, 396, 225-226. https://doi.org/10.1038/24293

Koenig, W. D., \& Knops, J. M. H. (2000). Patterns of annual seed production by northern hemisphere trees: a global perspective. American Naturalist, 155, 59-69. https://doi.org/10.1086/303302

Kolokotrones, T., Savage, V., Deeds, E. J., \& Fontana, W. (2010). Curvature in metabolic scaling. Nature, 464, 753-756. https://doi.org/10.1038/nature08920

Lagrue, C., Poulin, R., \& Cohen, J. E. (2015). Parasitism alters three power laws of scaling in a metazoan community: Taylor's law, density-mass allometry, and variance-mass allometry. Proceedings of National Academy of Sciences USA, 112, 1791-1796. https://doi.org/10.1073/pnas.1422475112

Marquet, P. A., Quiñones, R. A., Abades, S., Labra, F., Tognelli, M., Arim, M., \& Rivadeneira, M. (2005). Scaling and power-laws in ecological systems. Journal of Experimental Biology, 208, 1749-1769. https://doi.org/10.1242/jeb.01588

Milne, B. T. (1998). Motivation and benefits of complex systems approaches in ecology. Ecosystems, 1, 449-456. https://doi.org/10.1007/s100219900040

Morand, S., \& Krasnov, B. 2008. Why apply ecological laws to epidemiology? Trends in Parasitology, 24, 304-309. https://doi.org/10.1016/j.pt.2008.04.003

Noss, R. F., LaRoe, E. T., \& Scott, J. M. (1995). Endangered ecosystems of the United States: a preliminary assessment of loss and degradation. USDI National Biological Service, Biological Report, 28, Washington D.C.

Outcalt, K. W., \& Sheffield, R. M. (1996). The longleaf pine forest: Trends and current conditions. USDA Forest Service, Southern Research Station, Resource Bulletin SRS-9. https://doi.org/10.2737/SRS-RB-009

Patterson, T. W. (2017). Longleaf pine masting, climate variability, and tick-borne disease prevalence in the southeastern US (PhD Dissertation). Greensboro, NC: The University of North Carolina at Greensboro.

Pederson, N., Kush, J. S., \& Meldahl, R. S. (1998). Correlating climate and longleaf pine cone crops. In Is there a connection? Proceedings of the 2nd Longleaf Alliance Conference, November 17-19, 1998. Charleston, SC. Longleaf Alliance Report, 4. 140-143. Auburn University, AL: Longleaf Alliance.

Pederson, N., Kush, J. S., Meldahl, R. S. \& Boyer, W. D. (2000). Longleaf pine cone crops and climate. In L. A. Shreveport, \& J. D. Haywood (Eds.), A possible link: Proceedings of the tenth biennial southern silvicultural research conference (pp 255-258), February 16-18, 1999. Gen. Tech. Rep. SRS-30. Asheville, NC: U.S. Department of Agriculture, Forest Service, Southern Research Station.

Simini, F., Anfodillo, T., Carrer, M., Banavar, J. R., \& Maritan, A. (2010). Self-similarity and scaling in forest communities. Proceedings of National Academy of Sciences USA, 107, 7658-7662. https://doi.org/10.1073/pnas.1000137107

Suzuki, A. A., \& Suzuki, M. (2009). Why do lower order branches show greater shoot growth than higher order branches? Considering space availability as a factor affecting shoot growth. Trees, 23, 69-77. https://doi.org/10.1007/s00468-008-0255-2

West, G. F. (1999). The origin of universal scaling laws in biology. Physica A, 263,104-113. https://doi.org/10.1016/S0378-4371(98)00639-6

White, E. P., Enquist, B. J., \& Green, J. L. (2008). On estimating the exponent of power-law frequency. Ecology, 89, 905-912. https://doi.org/10.1890/07-1288.1

Zillio, T., \& Condit, R. (2007). The impact of neutrality, niche differentiation and species input on diversity and abundance distributions. Oikos, 116, 931-940. https://doi.org/10.1111/j.0030-1299.2007.15662.x 
Zipf, G. K. (1949). Human Behavior and the Principle of Least Effort. Cambridge, MA: Addison-Wesley Press.

\section{Copyrights}

Copyright for this article is retained by the author(s), with first publication rights granted to the journal.

This is an open-access article distributed under the terms and conditions of the Creative Commons Attribution license (http://creativecommons.org/licenses/by/3.0/). 